\title{
Federalismo e políticas sociais: conexões a partir da Teoria da Agência
}

José Angelo Machado

Universidade Federal de Minas Gerais (UFMG)

Neste trabalho, tratamos dos ganhos embutidos nas transferências condicionadas de recursos da União para governos subnacionais, que explicariam sua difusão em diversos setores governamentais, principalmente políticas sociais, nas últimas décadas. Analisamos os programas federais com maior volume de transferências condicionadas em três áreas governamentais - saúde, educação e assistência social - mobilizando achados da Teoria da Agência e sua aplicação ao estudo das relações intergovernamentais. Concluímos que, nos formatos vigentes, programas federais reduzem custos de agência ao padronizar e especificar ações executadas por governos subnacionais, condicionar transferências à adesão destes a tais padrões e admitir uma multiplicidade de "controladores", incluindo aqueles de natureza societal. Ao final, destacamos o papel das transferências condicionadas na superação dos efeitos da fragmentação territorial dos governos subnacionais sobre o processo de implementação das políticas públicas, ainda que a custo de reforçar a verticalização das relações intergovernamentais e tornar mais complexa a articulação intersetorial programática nos governos subnacionais.

Palavras-chave: federalismo, transferência intergovernamental, relações intergovernamentais, gestão de políticas públicas

[Artigo recebido em 22 de dezembro de 2015. Aprovado em 8 de setembro de 2016.] 


\section{Federalismo y política social: conexiones desde la Teoría de la Agencia}

Este artículo se ocupa de los beneficios de las transferencias condicionales de ingressos federales para los gobiernos subnacionales, lo que explicaría su difusión por diversos sectores del gobierno en las últimas décadas. Los programas federales con mayor volumen de transferencias condicionadas en tres áreas de gobierno - la salud, educación y asistencia social - se analizan en base a la Teoría de la Agencia y su aplicación a las relaciones intergubernamentales. Llegamos a la conclusión de que los programas federales reducen los costos de agencia mediante la estandarización y especificación de las acciones a realizar, acondicionamiento de las transferencias de ingresos y movilización de múltiples "controladores". Al final se destaca el papel de los programas para superar efectos de la fragmentación territorial de los gobiernos subnacionales sobre el proceso de implementación de las políticas públicas, aunque integrando verticalmente las relaciones intergubernamentales y haciendo más compleja la colaboración intersectorial en los gobiernos subnacionales.

Palabras clave: federalism, intergovernmental transfer, intergovernmental relations, public policy management

\section{Federalism and social policy: connections from the Agency Theory}

This paper deals with the inherent gains on conditional transfers of grants from the Union to sub-national governments, which would explain its diffusion by several government sectors, mainly social policies, in recent decades. The federal programs with higher sum on three government areas - health, education and social assistance - are analyzed mobilizing findings of the Agency Theory and its application on intergovernmental relations. We concluded that, in present formats, federal programs reduce agency costs by standardizing and specifying the actions to be performed by sub-national governments, conditioning transfers of grants and admitting a multiplicity of "controllers", including those of a societal nature. At the end we highlight the role of transfers to overcome the effects of territorial fragmentation of subnational governments on the implementation of public policies, although strengthening the vertical integration of intergovernmental relations and making more complex the intersectoral coordination at the local level.

Keywords: federalism, intergovernmental transfer, intergovernmental relations, public policy management 


\section{Introdução}

Os padrões de formulação e implementação de políticas sociais no Brasil pós Constituição Federal de 1988, tendo alcançado distintos formatos e níveis de estabilidade nas diferentes áreas governamentais, experimentaram também combinações específicas entre mecanismos de coordenação intergovernamental. Tais mecanismos incluíram constrangimentos constitucionais ou legais, vinculando diferentes níveis de governo a determinadas regras para gastos ou responsabilidades no desenvolvimento de determinada política pública. Incluíram também, em algumas políticas sociais, a constituição de arenas institucionalizadas para decisões relativas à implementação dessas políticas, nas quais a dimensão federativa ocupa posição central ou, pelo menos, relevante na sua composição. E incluíram, além de outros mecanismos, transferências de recursos para governos subnacionais atuarem na implementação dessas políticas, geralmente por meio da adesão a programas federais, em muitos casos estruturantes para a realização das garantias sociais aportadas pelo Estado brasileiro aos seus cidadãos em dimensão nacional.

Neste trabalho, buscamos elucidar quais teriam sido as vantagens inerentes às transferências condicionadas de recursos, da União para governos subnacioniais, que explicariam sua difusão por diversos setores governamentais, principalmente políticas sociais, nas últimas décadas. Para tanto, propomos analisar aspectos normativos dos programas federais com maior volume de transferências condicionadas em três áreas governamentais: saúde, educação e assistência social. Mobilizando achados da Teoria da Agência e, particularmente, de sua aplicação ao estudo das relações intergovernamentais, chegamos à conclusão de que, nos formatos vigentes, programas federais reduzem custos de agência ao padronizar e delimitar as ações a serem executadas por governos subnacionais, ao condicionar o repasse de recursos à sua realização e ao dispor de uma multiplicidade de "controladores" que permite verificá-la, incluindo aqueles de natureza societal. Concluímos, por fim, que a difusão desse mecanismo, típico do federalismo centralizado, embora não exclusivo deste, tem permitido compensar a fragmentação territorial produzida pelo federalismo trino brasileiro, em sentido horizontal, porém sob o prejuízo da produção de efeitos não desejados, entre os quais a baixa integração programática das políticas sociais ou, em outras palavras, sob o acirramento da sua fragmentação vertical.

\section{Fragmentação territorial, cooperação e centralização}

O caráter nacional da provisão dos direitos sociais assegurados pela Constituição Federal de 1988 foi desafiado pelo arranjo federativo que emergiu da mesma, na medida em que incorporou três níveis de governo, uma vez atribuído o status de 
membros da Federação aos municípios. A fragmentação político-territorial que, em tese, resultaria dessa característica e que nos primeiros anos após a promulgação da nova Carta Magna levou à formação de padrões de comportamento competitivos e predatórios nas relações horizontais entre governos subnacionais (ABRUCIO, 2005), não veio a ser um problema sem solução. A própria Constituição Federal de 1988 estabeleceu responsabilidades compartilhadas em várias políticas públicas e deixou, à União, os recursos institucionais para sua regulamentação em diferentes áreas de políticas públicas (ALMEIDA, 2007; ARRETCHE, 2012).

Ainda sobre as competências compartilhadas, não são raras, na literatura política brasileira, referências à ideia de que a Constituição Federal de 1988 tenha incorporado atributos marcadamente característicos do chamado federalismo cooperativo (ALMEIDA, 2000, 2005), ainda que isso não signifique necessariamente a ausência (SouZA, 2005) ou mesmo a superação de um padrão de relações competitivas coexistente (FRANZESE, 2010). É preciso esclarecer que a definição para federalismo cooperativo não diz respeito, propriamente, à constatação fática da predominância de comportamentos mutuamente ajustados nas relações intergovernamentais (cooperativos), mas, antes e apenas, ao compartilhamento da jurisdição sobre áreas governamentais entre a União e estados federados. Proposta pela $\mathrm{ACIR}$ (Advisory Commission on Intergovernmental Relations ${ }^{1}$ ), tal definição compõe uma tipologia na qual se contrapõe ao federalismo dual, em que governo nacional e dos estados, mesmo atuando sobre o mesmo território, exercem seus poderes separada e independentemente em áreas governamentais atribuídas pela Constituição; e ao federalismo centralizado, no qual estados se tornam agentes administrativos da União, detentora de poder regulamentador e recursos para induzi-los a agir segundo suas preferências.

No caso brasileiro, segundo Almeida (2000 e 2005), a Constituição Federal de 1988 marcou a passagem de um federalismo centralizado para um padrão cooperativo e descentralizado, implicando a definição de novas formas e mecanismos de cooperação, bem como a descentralização de competências e atribuições da esfera federal para a estadual e, sobretudo, para a municipal. Entretanto tal transição teria esbarrado em obstáculos decorrentes de uma dupla exigência: o controle da inflação e o exercício de austeridade fiscal, que marca os anos 1990; e as dificuldades do Executivo para construir mecanismos de cooperação que acelerassem o processo de descentralização sem prejuízo ao caráter nacional das políticas, problema que variou de uma área governamental para outra.

\footnotetext{
${ }^{1}$ Agência independente e bipartidária, instituída pelo Congresso Americano em 1959 para estudar e propor recomendações envolvendo relações intergovernamentais nos Estados Unidos, a ACIR foi extinta em 1996.
} 
Vale lembrar que o artigo 23 da Constituição Federal, que delimitou as áreas de competências comuns entre os três níveis de governo, em seu parágrafo único, havia definido que lei complementar fixaria "normas para a cooperação" entre os respectivos entes, não tendo sido regulamentado posteriormente. A ausência de mecanismos constitucionais ou institucionais que estimulassem a cooperação, bem como as profundas assimetrias de capacidades entre os entes federados teriam levado a uma precária concretização do federalismo cooperativo, segundo Souza (2005), deixando espaço aberto para o desenvolvimento de relações competitivas. Franzese (2010), por outro lado, caracterizou a Constituição Federal como um híbrido institucional que combina elementos favoráveis à cooperação e à competição, os primeiros derivados do compartilhamento de atribuições e os últimos da descentralização. Mas igualmente se ressente de que a Constituição não tenha indicado "quais formas devem ser utilizadas para levar essa cooperação a efeito" (FRANZESE, 2010, p. 94), o que também, na sua visão, explicaria o padrão fragmentado e competitivo de relações intergovernamentais nos primeiros anos após sua promulgação.

Entretanto, a reversão desse mesmo padrão, a partir de meados dos anos 1990, foi marcada pela retomada do protagonismo da União na definição da direção e do ritmo de desenvolvimento das políticas sociais. Movimento cujo alcance foi capturado, na literatura política brasileira, sob interpretações diversas.

Souza (2005, p. 114) percebeu que, em várias políticas sociais, as diretrizes e recursos federais passaram a guiar a implementação, principalmente nos municípios, mas que, em outras políticas, as relações permaneceram "altamente competitivas, tanto vertical como horizontalmente, e marcadas pelo conflito". Em outro trabalho (SoUZA, 2013), a mesma autora chamou atenção para o protagonismo do Governo Federal na realização de reformas constitucionais que tiveram impacto nas relações intergovernamentais, ainda que isso não signifique que sua agenda seja aprovada sem necessidade de negociações e barganhas junto aos governos subnacionais. Já para Almeida (2005, p. 37-38), nas políticas sociais, a descentralização de responsabilidades para os municípios "significou coisas diferentes e ocorreu em ritmos diferentes, de acordo com o desenho específico de cada política" de modo que, enquanto na saúde a União "detém o controle do processo decisório, definindo o formato da cooperação e a destinação dos recursos transferidos", na educação básica, por exemplo, sua forte influência conviveu com maior controle dos estados e municípios sobre os recursos correspondentes. Abrucio (2005) elencou um conjunto de mecanismos que permitiu à União coordenar políticas sociais de abrangência nacional, entre os quais, especialmente nas áreas de saúde e educação, foi decisivo o repasse condicionado de recursos. Também nessa última direção, Arretche viu, 
na indução das escolhas dos governos locais por meio de programas federais com transferência condicionada de recursos, o motor de transformações estruturantes na montagem do Sistema Único de Saúde (ARRETCHE, 2003) e em outras políticas públicas (ARRETCHE, 2004), sendo tais mecanismos construídos a partir dos próprios recursos institucionais previstos na Constituição Federal de 1988 (ARRETCHE, 2009).

No conjunto dessas abordagens, em que pese a menção à produção de constrangimentos constitucionais e legais - Lei de Responsabilidade Fiscal, pisos constitucionais para gasto com saúde e educação, entre outros - ou a arenas de pactuação intergestores ${ }^{2}$, há uma forte convergência em torno da importância dos programas federais com transferências condicionadas para promover a articulação das ações de governo em torno do "que fazer" e do "como fazer" nas políticas sociais. Mais precisamente, desde o início dos anos 2000, a maior parte das despesas discricionárias federais, com políticas sociais, passou a ser executada mediante transferências para estados e municípios, embora a dominância desse padrão não ocorra em todos os setores dessas políticas (MACHADO, 2011). Nesse último trabalho, aliás, constatou-se que, dentro do volume de transferências discricionárias para os setores de saúde, educação e assistência social, aquelas realizadas com finalidade específica, em caráter condicional e de forma regular para a implementação de programas federais ${ }^{3}$ se tornaram majoritárias, chegando a representar mais de $90 \%$ dos recursos transferidos para estados e municípios no caso do setor saúde, embora nas outras áreas esse percentual não seja tão elevado.

A questão que emerge daí é como interpretar o papel de destaque dos programas federais com transferências condicionadas enquanto mecanismo de coordenação federativa na implementação de políticas sociais, uma vez identificado nosso federalismo como predominantemente cooperativo, em vista do compartilhamento de responsabilidades. Estaríamos diante de alguma anomalia ou deformação deste último, provavelmente extirpada, caso nossa institucionalidade contivesse os mecanismos de cooperação "prometidos" pelo artigo 23 da Constituição Federal? Ou seriam as transferências condicionadas um recurso inevitável para

\footnotetext{
${ }^{2}$ Citamos aqui as comissões intergestores tripartite das áreas de saúde e assistência social e a Comissão Intergovernamental de Financiamento para a Educação Básica de Qualidade. Embora esses fóruns tenham sido percebidos por Franzese (2010) como espaços de negociação federativa, que caracterizam o federalismo cooperativo, por meio de um estudo sistemático de todas as atas de reuniões dessas comissões até 2010, Palotti (2012) colheu várias indicações de que a União detém, não apenas a iniciativa da introdução dos temas na agenda, como detém outros recursos estratégicos para encaminhar, por outras vias, assuntos que possam encontrar resistências das representações nacionais dos estados e municípios.

${ }^{3}$ Convênios ou contratos de repasse, por exemplo, não estão aqui incluídos, dada a transitoriedade temporal com que operam na execução de projetos, programas ou atividades. Trata-se, portanto, de transferências de recursos com vigência indeterminada e mediante regras de transferência fixadas aplicáveis genericamente a todo e qualquer estado ou município que venha aderir ao programa federal.
} 
levar adiante a implementação descentralizada de políticas nacionais, dada a elevada fragmentação territorial dos governos municipais, protagonistas na maior parte delas? Se as transferências condicionadas se disseminaram, e continuam a se disseminar, em diferentes setores governamentais, que vantagens ou ganhos teriam animado sua adoção pelo Executivo federal?

É nessa direção que nos propomos, neste trabalho, à luz da Teoria da Agência, a explorar e interpretar aspectos do desenho normativo de programas federais sociais com transferências condicionadas, a fim de encontrar, no próprio desenho dos mesmos, elementos que nos ajudem a explicar sua disseminação em detrimento de outas estratégias de coordenação e cooperação.

Na próxima seção faremos uma breve apresentação da Teoria da Agência, destacando algumas de suas proposições centrais e aspectos relevantes, bem como limites à sua aplicação às relações intergovernamentais. Na terceira seção, com base em eixos de análise previamente definidos, analisamos aspectos normativos de cinco programas com transferências condicionadas e regulares, selecionando aqueles que mais movimentam recursos em cada uma das áreas governamentais escolhidas - saúde, educação e assistência social -, a fim de compará-los, na busca pela identificação de padrões e distinções. Por fim, na última seção, construímos uma interpretação para escolhas governamentais subjacentes aos padrões e distinções encontrados e, a partir daí, discutimos suas implicações para uma caracterização do federalismo brasileiro contemporâneo.

\section{Federalismo e Teoria da Agência}

Oriunda dos domínios da Economia e aplicada à Ciência Política já há algum tempo, a Teoria da Agência refere-se a um tipo particular de relação entre duas ou mais partes em que alguma, designada como agent, atua em favor ou como representante de outra, designada principal (Ross, 1973). O elemento distintivo dessa relação é a configuração de uma estrutura assimétrica, uma vez que, nas palavras de Miller (2005), a autoridade está alocada em um lado e a vantagem informacional no outro. Isso quer dizer que, enquanto o principal detém algum tipo de poder ou autoridade para manipular os incentivos que induzem as ações do agent no seu interesse, este último detém mais informações sobre as condições em que irá atuar, sobre os cursos de ação possíveis e sobre os possíveis resultados a partir da escolha de cada um destes.

Os problemas de agência decorrem do fato de que, nessa estrutura relacional, principal e agent são sujeitos com funções de utilidade próprias (Ross, 1973), o que significa que cada um buscará manipular os meios de modo a produzir os resultados de sua preferência. Por esse motivo, o agent, como representante do 
principal, não necessariamente age na mesma direção e com a mesma intensidade com que aquele agiria. Uma vez detendo mais informações que o principal, o agent tem a possibilidade de assumir cursos de ação que, afetando os payoffs de ambos, maximizem seus ganhos em detrimento daqueles retribuídos ao primeiro.

Os riscos de "traição" do agent constituem um problema a ser, em alguma medida, contornado nos arranjos institucionais que dão suporte às relações entre as duas partes, sob pena do sacrifício da sua continuidade. Na medida em que o principal detém poder suficiente para impor uma estrutura de incentivos ao agent, a resolução do referido problema depende da qualidade desses incentivos para fazer com que o "mais esperto dos agents" escolha o curso de ação preferido pelo principal, caso tivesse o mesmo nível de informação (MILLER, 2005). Porém a operação dessa estrutura de incentivos tem custos para o principal, implicando dispêndio de recursos no desenho do contrato, monitoramento do seu cumprimento e execução das sanções diante de eventuais desvios. Estes são os chamados custos de agência.

Postos esses elementos, é possível entender por que boa parte da literatura sobre os problemas de agência, tanto na Economia quanto na Ciência Política, vai se dedicar à identificação de condições de eficácia dessa estrutura de incentivos, seja sob contratos que regulam transações econômicas ou sob regras institucionais que regulam as relações entre atores políticos como, por exemplo, aquelas estabelecidas entre representantes e representados. Se, como dito anteriormente, o principal tipicamente detém o poder de manipular a estrutura de incentivos, caberia ao mesmo realizar o primeiro movimento e oferecer o contrato ao agent, porém levando em conta as preferências deste último a fim de que tal contrato possa produzir a melhor resposta. Entretanto, o conhecimento das preferências do agent pelo principal não é uma condição trivial e, juntamente com outras dimensões da assimetria informacional entre os dois lados, pode tornar o desenho da estrutura de incentivos um empreendimento deveras complexo. Especificamente no que toca aos problemas de agência que se desenvolvem na esfera política, alguns atributos institucionais se mostram importantes para que o principal tenha sucesso na estruturação dos incentivos para atuação do agent, embora nem sempre sua implementação seja simples ou mesmo viável.

Um primeiro atributo seria a especificação, pelo principal, das ações a serem desempenhadas pelo agent, instruindo-o claramente e restritamente sobre o comportamento a ser adotado. Porém esse atributo institucional não é de fácil implementação. Geralmente a "melhor ação" a ser executada pelo agent no interesse do principal depende de contingências dos cenários nos quais atua, ou seja, sua escolha pode requerer algum nível de discricionariedade por sua parte. 
Esse é o limite identificado por Przeworski (1998) quanto à especificação da atuação das agências administrativas ou governamentais no melhor interesse dos cidadãos: seria impossível descrever, por meio de uma legislação, a plena instrução do que os agentes públicos devem fazer sob todas as circunstâncias possíveis, além de que são estes últimos que, na grande maioria das vezes, são os que detêm as informações sobre quais são de fato as circunstâncias encaradas.

Mas, se a instrução perfeita é uma condição demasiado irrealista para ser almejada, algum nível de restrição de ações a partir da descrição de atribuições e responsabilidades do agent pode ser possível, o que desloca o problema da eficácia da estrutura de incentivos para um segundo atributo institucional: o monitoramento do comportamento do agent pelo principal. A observação das ações do primeiro permitiria que este último avaliasse se estaria ou não agindo no seu melhor interesse, dados alguns parâmetros de ação previamente delimitados, ainda que genéricos.

Porém apenas observar a atuação do agent ainda não bastaria para solucionar os problemas de agência. Uma vez que, para reestabelecer a direção e intensidade da sua atuação no interesse do principal, constrangendo eventuais desvios, tal monitoramento deve vir acompanhado de algum mecanismo de sanção ou retaliação. A eficácia do sistema de incentivos na indução do comportamento do agent requer, portanto, que a instituição que regula as relações entre as duas partes não apenas forneça os instrumentos que asseguram a visibilidade desse comportamento, mas também os que asseguram a sua correção.

Porém o exercício direto das funções de monitoramento e sanção pelo principal nem sempre é tecnicamente possível ou executada a custos factíveis, o que pode tornar necessário o desenvolvimento de mais um atributo institucional: o compartilhamento dessas funções com outros atores colocados numa posição idêntica à do principal, como quem dividiriam o papel de realização dos controles ou checks. Trata-se da designação de múltiplos principals envolvidos no controle do comportamento do agent, ainda que tal controle venha a ser exercido no sentido de realizar seus atributos institucionais mais restritos. A construção de cadeias de checks and balances, em sentido vertical ou horizontal (PRZEWORSKI, 1998), envolve, portanto, outros atores institucionais com autoridade para acompanhar, vetar ou sancionar a conduta dos agents, como ocorre na figura dos tribunais de contas, conselhos de políticas públicas ou do instituto do Ministério Público, no caso brasileiro.

Não sendo nossa intenção, a esta altura, exaurir a relação de atributos institucionais relevantes para a promoção da eficácia de estruturas de incentivos voltados para a resolução dos problemas de agência na esfera política, nos limitamos 
aqui apenas a estes, tanto pelo seu caráter geral na compreensão do fenômeno quanto pela sua utilidade analítica na identificação de aspectos que serão abordados adiante neste trabalho. Antes, porém, vale registrar algumas avaliações sobre a aplicabilidade da Teoria da Agência ao campo das relações intergovernamentais.

Em uma delas, Oates (2005) considera tal aplicação uma das direções tomadas por uma segunda geração de teorias desenvolvidas no campo de estudos do federalismo fiscal. Assumem-se governos regionais ou locais como se comportando de forma a promover os objetivos do governo central, com poderes mais proeminentes na estruturação das relações fiscais intergovernamentais, embora detendo informação imperfeita e controle limitado sobre as atividades fiscais descentralizadas. Uma das estratégias para indução seria exatamente a limitação da flexibilidade da provisão de serviços pelos governos locais, de forma a constranger a alocação dos recursos de fundos ou programas nacionais. Mas o autor critica tal aplicação, realçando que a mesma ignora a concorrência da dimensão eleitoral a que se submetem os gestores regionais ou locais, além de que seria restrita aos casos de países em que prevalece o federalismo "administrativo".

Em outra, Löffler (2000, p. 16, grifo nosso) destaca que a Teoria da Agência não seria um "quadro correto para a análise das relações de responsabilização dentro de parcerias" intergovernamentais, já que "supõe uma transferência de tarefas entre dois parceiros com uma relação desigual de poder, enquanto que o conceito de parcerias é baseado na delegação de responsabilidade entre dois parceiros iguais". No entanto, a autora ressalta que, especialmente no caso das parcerias verticais intergovernamentais, a teoria "tem o mérito de sublinhar os desequilíbrios de poder e informações" e que, ainda que "de uma perspectiva jurídica todos os parceiros sejam autônomos, na realidade, pode haver uma relação de agente principal". A aplicabilidade da teoria ao objeto, portanto, dependeria da configuração específica deste último, não sendo a autora explícita se isso a tornaria mais ou menos restritiva.

Por fim, Levaggi (2002) assume que tal aplicação seria extensível a casos em que a implementação de políticas públicas requer que a esfera detentora do orçamento, o governo central, opere sob um ambiente de incerteza em que não tem capacidades diretas de provisão de serviços, mobilizando governos regionais ou locais para tanto. Entretanto, destaca, trata-se de uma atípica relação de agência, dado que a assimetria de informação entre as duas partes não se combina com um mercado competitivo de vários agents ou governos locais, que concorressem para ser contratados. O governo central depende deles para implementar a política, e a descentralização, sob a assimetria de informação, pode ser desastrosa, considerando 
que aqueles governos têm mais informação sobre quantidades e qualidades dos serviços a serem providos, bem como de seus custos locais, procedendo a escolhas agregadas potencialmente incongruentes com as dimensões gerais do orçamento nacional e com o nível de utilidade do eleitor mediano nacional. Disso decorre o governo central formular programas como "contratos" em que delega a produção e provisão dos serviços, porém delimitando os atributos destes últimos a fim de assegurar a congruência com seus objetivos orçamentários e eleitorais.

No que se refere ao caso brasileiro, como apontado na seção anterior, a literatura sobre federalismo tem incorporado a percepção de que, desde meados dos 1990, a União fez valer suas prerrogativas constitucionais para legislar sobre políticas públicas de responsabilidade compartilhada (ARRETCHE, 2012), recuperando capacidades institucionais e financeiras (ALMEIDA, 2005, 2007). Moldou, assim, um padrão de "descentralização regulada" (ARRETCHE, 2012) - fundada na divisão das funções de policy decision making e policy making, respectivamente atribuídas ao Governo Fentral e governos subnacionais. Porém, a despeito do reconhecimento da verticalização das relações intergovernamentais na operação da descentralização regulada, em especial nas políticas sociais, ainda são poucas as referências explícitas à "agencificação" destes últimos (MACHADO; PALOTTI, 2015).

No intuito de contribuir para essa discussão, analisamos, na próxima seção, os mecanismos de transferência de recursos da União para governos subnacionais em políticas e programas sociais nas áreas de saúde, educação e assistência social que mobilizaram maior aporte de recursos financeiros em cada um desses setores em 20094. Tais políticas e programas sociais podem ter origem constitucional (Fundo de Manutenção e Desenvolvimento da Educação Básica e de Valorização dos Profissionais da Educação - Fundeb), legal (Programa Nacional de Alimentação Escolar - PNAE, Programa Nacional de Apoio ao Transporte Escolar - PNATE, Programa Dinheiro Direto na Escola - PDDE e Salário Educação) ou ato normativo ministerial (todos das áreas de saúde e assistência social). Envolvem transferências diretas de recursos da União para fundos estaduais ou municipais setoriais, sem necessidade de convênio, e estão submetidos a condições gerais, aplicáveis a todos os governos subnacionais.

\footnotetext{
${ }^{4}$ A seleção foi realizada como parte da pesquisa Relações intergovernamentais e coordenação de políticas sociais: eficácia e contenção do poder no desenho dos incentivos financeiros federais, apoiada financeiramente pelo Conselho Nacional de Desenvolvimento Científico e Tecnológico (CNPq) e Fundação de Amparo à Pesquisa do Estado de Minas Gerais (Fapemig), concluída em 2011. O ano de 2009 era, então, o último para o qual tínhamos as informações para os gastos simultaneamente nos três setores pesquisados.
} 


\section{Programas federais com transferências intergovernamentais}

Para análise dos mecanismos de transferência de recursos, foi mobilizada a legislação e normatização na qual foram estabelecidos e passaram por modificações mais significativas, conforme consta do Quadro 1, a seguir.

Quadro 1 - Base legal e normativa das transferências intergovernamentais analisadas e montante de recursos empenhado em 2009

\begin{tabular}{|c|c|c|c|}
\hline $\begin{array}{l}\text { Setor } \\
\text { governamental }\end{array}$ & Incentivos & Instrumentos normativos & $\begin{array}{l}\text { Total desembolsado } \\
\text { em } 2009 \text { (em R\$) }\end{array}$ \\
\hline \multirow{5}{*}{ Saúde } & $\begin{array}{l}\text { Teto financeiro } \\
\text { média e alta } \\
\text { complexidade }\end{array}$ & $\begin{array}{l}\text { Norma Operacional de Assistência } \\
\text { á Saúde 01/2002; Portarias } \\
\text { ministeriais 699/GM, de 30/03/ } \\
\text { 2006; 204/GM de 29/01/ 2007; e } \\
\text { 399/GM de 22/02/2006. }\end{array}$ & 19.150.151.558,67 \\
\hline & $\begin{array}{l}\text { Piso de atenção } \\
\text { básica fixo }\end{array}$ & $\begin{array}{l}\text { Portarias ministeriais 204/GM de } \\
\text { 29/01/ 2007; 648/GM de 28/03/ } \\
\text { 2006; 399/GM de 22/02/ 2006; } \\
\text { 2048/GM de 2009 - Regulamento } \\
\text { do SUS. }\end{array}$ & 3.099.326.556,41 \\
\hline & Saúde da família & $\begin{array}{l}\text { Portarias ministeriais 204/GM de } \\
\text { 29/01/ 2007; 648/GM de 28/03/ } \\
2006 .\end{array}$ & 2.475.944.300,00 \\
\hline & $\begin{array}{l}\text { Medicamentos } \\
\text { excepcionais }\end{array}$ & $\begin{array}{l}\text { Portaria GM-MS № 1.481, de } \\
\text { 28/12/ 1999; Portarias 204/GM de } \\
\text { 29/01/ } 2007 \text { e 2.577/GM de 27/10/ } \\
2006 \text {. }\end{array}$ & 2.062.588.097,83 \\
\hline & $\begin{array}{l}\text { Fundo de ações } \\
\text { estratégicas e } \\
\text { compensação / } \\
\text { nefrologia }\end{array}$ & $\begin{array}{l}\text { Portarias ministeriais 204/GM de } \\
\text { 29/01/ 2007; 399/GM de 22/02/ } \\
\text { 2006; 1168/GM de 15/06/2004; } \\
\text { SAS } 211 \text { de } 15 / 06 / 2004 ; 1112 / G M \\
\text { de } 13 / 06 / 2002 ; 1.603 \text { de } 17 / 07 / \\
2006 ; 2.048 \text {, de } 3 / 9 / 2009 \text {. }\end{array}$ & 1.613.322.264,84 \\
\hline
\end{tabular}




\begin{tabular}{|c|c|c|c|}
\hline $\begin{array}{l}\text { Setor } \\
\text { governamental }\end{array}$ & Incentivos & Instrumentos normativos & $\begin{array}{l}\text { Total desembolsado } \\
\text { em } 2009 \text { (em R\$) }\end{array}$ \\
\hline \multirow{5}{*}{ Educação } & $\begin{array}{l}\text { Fundo de } \\
\text { Manutenção e } \\
\text { Desenvolvimento } \\
\text { da Educação Básica } \\
\text { e de Valorização } \\
\text { dos Profissionais da } \\
\text { Educação (Fundeb) }\end{array}$ & $\begin{array}{l}\text { Emenda Constitucional } 14 \text { / 1996; } \\
\text { Emenda Constitucional } 53 \text { / } \\
\text { 2006; Lei } 11.494 / 2007 \text { e Decreto } \\
6.253 / 2007 .\end{array}$ & $5.070 .150 .000,00$ \\
\hline & Salário-educação & $\begin{array}{l}\text { Lei 4.440/1964; Constituição } \\
\text { Federal (artigo 212, § 5); Lei } \\
\text { 9.424/1996 e 9.766/1998; Decreto } \\
\text { 6003/2006; Lei 11.457/2007. }\end{array}$ & $5.265 .064 .097,73$ \\
\hline & $\begin{array}{l}\text { Programa Nacional } \\
\text { de Alimentação } \\
\text { Escolar (PNAE) }\end{array}$ & $\begin{array}{l}\text { Constituição Federal (artigo } \\
\text { 208, incisos IV e VII); Portaria do } \\
\text { Ministro da Educação } 251 \text { / 2000; } \\
\text { Medida Provisória 2178-36/2001; } \\
\text { Lei } 11.947 \text { / } 2009 .\end{array}$ & $2.013 .251 .967,30$ \\
\hline & $\begin{array}{l}\text { Programa Dinheiro } \\
\text { Direto na Escola } \\
\text { (PDDE) }\end{array}$ & $\begin{array}{l}\text { Resolução do Ministro da Educação } \\
12 \text { / 1995; Medida Provisória 2.178- } \\
\text { 36/2001; Lei } 11.947 \text { / } 2009 .\end{array}$ & $1.036 .708 .651,40$ \\
\hline & $\begin{array}{l}\text { Programa Nacional } \\
\text { de Apoio ao } \\
\text { Transporte Escolar } \\
\text { (PNATE) }\end{array}$ & $\begin{array}{l}\text { Lei 10.880/2004; Medida Provisória } \\
\text { 455/2009; Lei } 11.947 \text { / } 2009 .\end{array}$ & $420.072 .734,54$ \\
\hline \multirow{5}{*}{$\begin{array}{l}\text { Assistência } \\
\text { social }\end{array}$} & $\begin{array}{l}\text { Î́ndice de Gestão } \\
\text { Descentralizada } \\
\text { (IGD) }\end{array}$ & $\begin{array}{l}\text { Lei No 10.836/2004; Lei no } 12.058 / \\
\text { 2009; Portaria 148, de 27/04/ 2006; } \\
\text { Portaria 220, de 25/06/ } 2008 \text {. }\end{array}$ & $256.671 .070,21$ \\
\hline & $\begin{array}{l}\text { Piso Básico Fixo } \\
\text { (PBF) - Família }\end{array}$ & $\begin{array}{l}\text { Portaria 442, de 26/08/ 2005; } \\
\text { Resolução 3, de 3/06/ 2008; } \\
\text { Portaria 288, de 2/09/2009; } \\
\text { Portaria 96, de 26/03/ 2009; }\end{array}$ & $250.877 .100,00$ \\
\hline & $\begin{array}{l}\text { Piso Social Básico - } \\
\text { Idoso / Infância }\end{array}$ & $\begin{array}{l}\text { Portaria 442, de 26/08/ 2005; } \\
\text { Resolução 3, de 3/06/ 2008; } \\
\text { Portaria 96, de 26/03/2009; } \\
\text { Portaria 288, de 2/09/2009 }\end{array}$ & $242.542 .294,79$ \\
\hline & $\begin{array}{l}\text { Piso Social } \\
\text { Especializado } \\
\text {-Programa de } \\
\text { Erradicação do } \\
\text { Trabalho Infantil } \\
\text { (PETI/JOR) }\end{array}$ & $\begin{array}{l}\text { Instrução Operacional SNAS/MDS } \\
\text { N}^{\circ} \text { 01, de 19/09/ 2007; Portaria } \\
\text { 458, de 4/10/ 2001; Portaria 666, } \\
\text { de 28/12/ 2005; Portaria 431, de } \\
\text { 3/12/ } 2008\end{array}$ & $192.892 .780,00$ \\
\hline & $\begin{array}{l}\text { Piso Social Básico - } \\
\text { Variável - Projovem }\end{array}$ & $\begin{array}{l}\text { Lei № 11.692/ 2008; Portaria 442, } \\
\text { de 26/08/ 2005; Resolução 3, de } \\
\text { 3/06/ 2008; Portaria 288, de 2/09/ } \\
\text { 2009; Portaria 96, de 26/03/ 2009; } \\
\text { Portaria 171, de 26/05/ } 2009\end{array}$ & $135.516 .712,50$ \\
\hline
\end{tabular}

Fonte: Machado (2011) - relatório de pesquisa. 
Além disso, com base na discussão dos atributos institucionais mencionados na seção anterior, buscamos construir eixos de análise com finalidades de verificação e comparação entre os mecanismos estudados, sendo ao final estabelecidos os seguintes: (1) Especificação das ações a serem desempenhadas pelo agent por parte do principal: maior ou menor restrição para uso dos recursos transferidos; (2) Monitoramento do comportamento do agent pelo principal: informação, controle e auditoria sobre ações dos executivos subnacionais; (3) Compartilhamento das funções de controle do agent com outros atores: outros agentes governamentais ou societais incumbidos de monitorar ou sancionar comportamentos dos executivos locais; (4) Mecanismo de sanções ou retaliação dos comportamentos indesejáveis do agent: previsão de penalidades ou suspensão de transferência de recursos por parte do Executivo federal. Com base nesses quatro eixos, serão analisadas, a seguir, as políticas de saúde, em primeiro lugar; posteriormente, assistência social; e, finalmente, educação.

O Quadro 2 resume a aplicação dos quatro eixos na análise das transferências selecionadas para a área da saúde. Quanto à especificação do uso dos recursos pelos governos receptores nos níveis subnacionais, a criação dos seis blocos de financiamento, reunindo vários mecanismos similares de transferência por nível de atenção e permitindo o remanejamento de recursos recebidos ${ }^{5}$, desde que dentro de um mesmo bloco, trouxe flexibilidade para realocação dos recursos em quatro dos cinco casos analisados. Apenas os recursos para o componente medicamentos excepcionais, executados pelos governos estaduais, não permitem tal possibilidade.

O monitoramento e controle do uso de recursos no Sistema Único de Saúde (SUS) conta com atuação do Sistema Nacional de Auditoria, no qual o componente federal tem papel central na auditagem do uso de recursos executados pelos municípios, ao passo que às secretarias estaduais de saúde cabe o monitoramento pela via dos relatórios de gestão municipais aprovados anualmente nos respectivos conselhos municipais de saúde. Esse padrão varia no caso do teto financeiro municipal PPI / MAC e nefrologia, em que a execução de metas físicas e financeiras de procedimentos é acompanhada pela Comissão Intergestores Bipartite $(\mathrm{CIB})^{6}$, e no caso dos medicamentos excepcionais, em que a auditoria federal do SUS atua sobre os estados executores.

A inclusão de outros atores no controle do uso dos recursos, no caso do SUS, segue praticamente o mesmo padrão: controle societal pela via dos conselhos de

\footnotetext{
${ }^{5}$ Foram criados os blocos de financiamento da atenção básica, média e alta complexidade, assistência farmacêutica, vigilância em saúde, gestão do SUS e investimentos na rede de serviços de saúde.

${ }^{6}$ Comissões paritárias entre Executivo estadual e representação dos Executivos municipais no âmbito de cada unidade da Federação.
} 
saúde, que fiscalizam, nos respectivos níveis de governo, as prestações de contas apresentadas pelos respectivos fundos de saúde; e, embora não explicitado nos atos normativos que instituem os mecanismos de transferência, controle externo dos tribunais de contas estaduais e do Tribunal de Contas da União.

Por fim, a principal sanção prevista na execução dos recursos é a suspensão da transferência de recursos em casos previamente tipificados, como não alimentação regular dos sistemas de informação do SUS ou indicações da Auditoria do SUS, havendo sempre previsão de prazos de defesa para os governos receptores dos recursos e procedimentos previamente definidos para os andamentos dos processos, a partir daí.

Quadro 2 - Análise dos mecanismos de transferências de recursos para governos subnacionais no setor saúde

\begin{tabular}{|c|c|c|c|c|c|}
\hline \multirow[b]{2}{*}{$\begin{array}{l}\text { Mecanismo de } \\
\text { transferência }\end{array}$} & \multirow[b]{2}{*}{ Destinação } & \multicolumn{4}{|l|}{ Eixos de análise } \\
\hline & & $\begin{array}{l}\text { Especificação } \\
\text { destinação dos } \\
\text { recursos }\end{array}$ & $\begin{array}{l}\text { Monitoramento } \\
\text { e controle } \\
\text { direto }\end{array}$ & $\begin{array}{l}\text { Monitoramento } \\
\text { de outros }\end{array}$ & $\begin{array}{l}\text { Sanção } \\
\text { desvio de } \\
\text { finalidade }\end{array}$ \\
\hline $\begin{array}{l}\text { Teto financeiro } \\
\text { municipal e } \\
\text { estadual da } \\
\text { PPI / Limite } \\
\text { financeiro } \\
\text { MAC }\end{array}$ & $\begin{array}{l}\text { Financiar } \\
\text { procedimen- } \\
\text { tos de média } \\
\text { e alta com- } \\
\text { plexidade, } \\
\text { de acesso } \\
\text { regional } \\
\text { pactuado } \\
\text { qualitativa } \\
\text { e quantita- } \\
\text { tivamente } \\
\text { em nível } \\
\text { intergover- } \\
\text { namental. }\end{array}$ & $\begin{array}{l}\text { Custeio da } \\
\text { oferta proce- } \\
\text { dimentos de } \\
\text { média e alta } \\
\text { complexidade } \\
\text { na rede pública } \\
\text { ou contratação } \\
\text { de prestadores } \\
\text { privados para o } \\
\text { mesmo fim. } \\
\text { Há possibilida- } \\
\text { de de rema- } \\
\text { nejamento } \\
\text { de recursos } \\
\text { para outros } \\
\text { componentes } \\
\text { e serviços } \\
\text { previstos nesse } \\
\text { mesmo bloco } \\
\text { de financia- } \\
\text { mento (MAC). }\end{array}$ & $\begin{array}{l}\text { Secretarias } \\
\text { estaduais (SES) } \\
\text { monitoram exe- } \\
\text { cução dos tetos } \\
\text { financeiros } \\
\text { pelos prestado- } \\
\text { res contratados } \\
\text { diretamente e } \\
\text { pelos municí- } \\
\text { pios (remeten- } \\
\text { do à comissão } \\
\text { intergestores } \\
\text { bipartite, se } \\
\text { necessário) e } \\
\text { Ministério da } \\
\text { Saúde audi- } \\
\text { ta por meio } \\
\text { do Sistema } \\
\text { Nacional de } \\
\text { Auditoria do } \\
\text { SUS. }\end{array}$ & $\begin{array}{l}\text { Conselhos muni- } \\
\text { cipais de saúde } \\
\text { devem aprovar } \\
\text { relatórios de ges- } \\
\text { tão e prestação } \\
\text { de contas dos } \\
\text { fundos munici- } \\
\text { pais de saúde, e, } \\
\text { analogamente, } \\
\text { os conselhos } \\
\text { estaduais de } \\
\text { saúde fazem } \\
\text { quando for o } \\
\text { caso de serviços } \\
\text { sob gestão das } \\
\text { secretarias es- } \\
\text { taduais. Embora } \\
\text { não previsto em } \\
\text { normatização do } \\
\text { SUS, TCU e TCE's } \\
\text { exercem controle } \\
\text { no contexto das } \\
\text { contas públicas } \\
\text { em geral. }\end{array}$ & $\begin{array}{l}\text { Ministério da } \\
\text { Saúde (MS) } \\
\text { pode suspen- } \\
\text { der repasse } \\
\text { em casos } \\
\text { previstos em } \\
\text { portaria: não } \\
\text { pagamento } \\
\text { dos presta- } \\
\text { dores até 5o } \\
\text { dia útil após } \\
\text { crédito pelo } \\
\text { MS; falta de } \\
\text { alimentação } \\
\text { dos bancos } \\
\text { de dados } \\
\text { nacionais; } \\
\text { auditoria } \\
\text { estadual ou } \\
\text { federal (há } \\
\text { prazos de } \\
\text { defesa para } \\
\text { município). }\end{array}$ \\
\hline
\end{tabular}




\begin{tabular}{|c|c|c|c|c|c|}
\hline \multirow[b]{2}{*}{$\begin{array}{l}\text { Mecanismo de } \\
\text { transferência }\end{array}$} & \multirow[b]{2}{*}{ Destinação } & \multicolumn{4}{|l|}{ Eixos de análise } \\
\hline & & $\begin{array}{l}\text { Especificação } \\
\text { destinação dos } \\
\text { recursos }\end{array}$ & $\begin{array}{l}\text { Monitoramento } \\
\text { e controle } \\
\text { direto }\end{array}$ & $\begin{array}{l}\text { Monitoramento } \\
\text { de outros }\end{array}$ & $\begin{array}{l}\text { Sanção } \\
\text { desvio de } \\
\text { finalidade }\end{array}$ \\
\hline PAB fixo & $\begin{array}{l}\text { Financiar } \\
\text { serviços } \\
\text { de atenção } \\
\text { básica em } \\
\text { saúde. }\end{array}$ & $\begin{array}{l}\text { Custeio da } \\
\text { oferta de } \\
\text { ações diversas } \\
\text { no nível de } \\
\text { atenção básica } \\
\text { previstos } \\
\text { nos planos } \\
\text { de saúde do } \\
\text { município. } \\
\text { Há flexibilidade } \\
\text { para remanejar } \\
\text { dentro do } \\
\text { mesmo } \\
\text { bloco de } \\
\text { financiamento } \\
\text { (atenção básica } \\
\text { - AB). }\end{array}$ & $\begin{array}{l}\text { Ministério da } \\
\text { Saúde audita } \\
\text { por meio } \\
\text { do Sistema } \\
\text { Nacional de } \\
\text { Auditoria } \\
\text { do SUS. SES } \\
\text { monitoram via } \\
\text { relatórios de } \\
\text { gestão. }\end{array}$ & \begin{tabular}{|l} 
Conselhos \\
municipais de \\
saúde devem \\
aprovar relatórios \\
de gestão e \\
prestação \\
de contas \\
dos fundos \\
municipais de \\
saúde. Embora \\
não previsto em \\
normatização do \\
SUS, TCU e TCE's \\
exercem controle \\
no contexto das \\
contas públicas \\
em geral.
\end{tabular} & $\begin{array}{l}\text { MS pode } \\
\text { suspender } \\
\text { em casos } \\
\text { previstos: } \\
\text { não } \\
\text { alimentação } \\
\text { das bases } \\
\text { de dados ou } \\
\text { indicação } \\
\text { de auditoria } \\
\text { nacional ou } \\
\text { estadual } \\
\text { mediante } \\
\text { desvio de } \\
\text { finalidade } \\
\text { dos recursos. } \\
\text { Auditoria } \\
\text { estadual e } \\
\text { federal (há } \\
\text { prazos de } \\
\text { defesa para o } \\
\text { município). }\end{array}$ \\
\hline $\begin{array}{l}\text { Saúde da } \\
\text { família }\end{array}$ & $\begin{array}{l}\text { Financiar } \\
\text { equipes de } \\
\text { saúde da } \\
\text { família. }\end{array}$ & $\begin{array}{l}\text { Custeio das } \\
\text { atividades da } \\
\text { equipe. } \\
\text { Há flexibilidade } \\
\text { para remanejar } \\
\text { dentro do } \\
\text { mesmo } \\
\text { bloco de } \\
\text { financiamento } \\
\text { (AB). Não há } \\
\text { possibilidade } \\
\text { de adaptação } \\
\text { local do } \\
\text { formato do } \\
\text { programa } \\
\text { fora do } \\
\text { detalhamento } \\
\text { estabelecido } \\
\text { pelo Ministério } \\
\text { da Saúde para } \\
\text { a atuação da } \\
\text { mesma. }\end{array}$ & $\begin{array}{l}\text { Ministério da } \\
\text { Saúde audita } \\
\text { por meio } \\
\text { do Sistema } \\
\text { Nacional de } \\
\text { Auditoria } \\
\text { do SUS. SES } \\
\text { monitoram via } \\
\text { relatórios de } \\
\text { gestão. }\end{array}$ & $\begin{array}{l}\text { Conselhos } \\
\text { municipais de } \\
\text { saúde devem } \\
\text { aprovar relatórios } \\
\text { de gestão e } \\
\text { prestação } \\
\text { de contas } \\
\text { dos fundos } \\
\text { municipais de } \\
\text { saúde. Embora } \\
\text { não previsto em } \\
\text { normatização do } \\
\text { SUS, TCU e TCE's } \\
\text { exercem controle } \\
\text { no contexto das } \\
\text { contas públicas } \\
\text { em geral. }\end{array}$ & $\begin{array}{l}\text { MS pode } \\
\text { suspender } \\
\text { em casos } \\
\text { previstos: } \\
\text { inexistência } \\
\text { unidade física } \\
\text { cadastrada; } \\
\text { ausência de } \\
\text { profissionais } \\
\text { maior } 90 \text { dias } \\
\text { ou descum- } \\
\text { primento de } \\
\text { carga horária. } \\
\text { Auditoria } \\
\text { estadual e } \\
\text { federal (há } \\
\text { prazos de } \\
\text { defesa para o } \\
\text { município). }\end{array}$ \\
\hline
\end{tabular}




\begin{tabular}{|c|c|c|c|c|c|}
\hline \multirow[b]{2}{*}{$\begin{array}{l}\text { Mecanismo de } \\
\text { transferência }\end{array}$} & \multirow[b]{2}{*}{ Destinação } & \multicolumn{4}{|l|}{ Eixos de análise } \\
\hline & & $\begin{array}{l}\text { Especificação } \\
\text { destinação dos } \\
\text { recursos }\end{array}$ & $\begin{array}{l}\text { Monitoramento } \\
\text { e controle } \\
\text { direto }\end{array}$ & $\begin{array}{l}\text { Monitoramento } \\
\text { de outros }\end{array}$ & $\begin{array}{l}\text { Sanção } \\
\text { desvio de } \\
\text { finalidade }\end{array}$ \\
\hline $\begin{array}{l}\text { Medicamentos } \\
\text { excepcionais }\end{array}$ & $\begin{array}{l}\text { Financiar } \\
\text { aquisição de } \\
\text { medicamen- } \\
\text { tos padroni- } \\
\text { zados nacio- } \\
\text { nalmente e } \\
\text { consumidos } \\
\text { regionalmen- } \\
\text { te. }\end{array}$ & $\begin{array}{l}\text { Aquisição } \\
\text { exclusiva de } \\
\text { medicamentos } \\
\text { de uso } \\
\text { excepcional. } \\
\\
\text { Recursos não } \\
\text { podem ser } \\
\text { remanejados } \\
\text { para comprar } \\
\text { medicamentos } \\
\text { de outro tipo. }\end{array}$ & $\begin{array}{l}\text { MS audita } \\
\text { por meio } \\
\text { do Sistema } \\
\text { Nacional de } \\
\text { Auditoria do } \\
\text { SUS através } \\
\text { do sistema de } \\
\text { informação que } \\
\text { gera autorização } \\
\text { para } \\
\text { procedimentos } \\
\text { de alta } \\
\text { complexidade } \\
\text { (APAC). }\end{array}$ & $\begin{array}{l}\text { Conselho } \\
\text { estadual de } \\
\text { saúde deve } \\
\text { aprovar relatórios } \\
\text { de gestão e } \\
\text { prestação de } \\
\text { contas do fundo } \\
\text { estadual de } \\
\text { saúde. Embora } \\
\text { não previsto em } \\
\text { normatização do } \\
\text { SUS, TCU e TCE's } \\
\text { exercem controle } \\
\text { no contexto das } \\
\text { contas públicas } \\
\text { em geral. }\end{array}$ & $\begin{array}{l}\text { MS pode } \\
\text { suspender } \\
\text { transferência } \\
\text { (indicação } \\
\text { de auditoria } \\
\text { nacional). } \\
\text { Nesse caso, } \\
\text { há prazos de } \\
\text { defesa para o } \\
\text { estado. }\end{array}$ \\
\hline Nefrologia & $\begin{array}{l}\text { Financiar } \\
\text { serviços de } \\
\text { hemodiálise } \\
\text { e procedi- } \\
\text { mentos afins } \\
\text { padroniza- } \\
\text { dos nacional- } \\
\text { mente. }\end{array}$ & $\begin{array}{l}\text { Custeio de } \\
\text { procedimentos } \\
\text { de média e alta } \\
\text { complexidade } \\
\text { de nefrologia, } \\
\text { conforme } \\
\text { previsto nos } \\
\text { planos de } \\
\text { trabalho. } \\
\text { Há flexibilidade } \\
\text { para remanejar } \\
\text { sobras dentro } \\
\text { do mesmo } \\
\text { bloco de } \\
\text { financiamento } \\
\text { (MAC). }\end{array}$ & $\begin{array}{l}\text { Secretarias } \\
\text { estaduais (SES) } \\
\text { monitoram } \\
\text { execução } \\
\text { dos tetos } \\
\text { financeiros } \\
\text { pelos } \\
\text { municípios } \\
\text { (remetendo } \\
\text { à comissão } \\
\text { intergestores } \\
\text { bipartite, se } \\
\text { necessário) e } \\
\text { Ministério da } \\
\text { Saúde audita } \\
\text { por meio } \\
\text { do Sistema } \\
\text { Nacional de } \\
\text { Auditoria do } \\
\text { SUS. }\end{array}$ & $\begin{array}{l}\text { Conselhos } \\
\text { municipais de } \\
\text { saúde devem } \\
\text { aprovar relatórios } \\
\text { de gestão e } \\
\text { prestação } \\
\text { de contas } \\
\text { dos fundos } \\
\text { municipais } \\
\text { de saúde, e, } \\
\text { analogamente, } \\
\text { os conselhos } \\
\text { estaduais de } \\
\text { saúde fazem } \\
\text { quando for o } \\
\text { caso de serviços } \\
\text { sob gestão das } \\
\text { secretarias } \\
\text { estaduais. } \\
\text { Embora não } \\
\text { previsto em } \\
\text { normatização do } \\
\text { SUS, TCU e TCE's } \\
\text { exercem controle } \\
\text { no contexto das } \\
\text { contas públicas } \\
\text { em geral. }\end{array}$ & $\begin{array}{l}\text { Ministério } \\
\text { da Saúde } \\
\text { (MS) pode } \\
\text { suspender } \\
\text { repasse } \\
\text { em casos } \\
\text { previstos em } \\
\text { portaria: não } \\
\text { pagamento } \\
\text { dos } \\
\text { prestadores } \\
\text { até 5o dia } \\
\text { útil após } \\
\text { crédito pelo } \\
\text { MS; falta de } \\
\text { alimentação } \\
\text { dos bancos } \\
\text { de dados } \\
\text { nacionais; } \\
\text { auditoria } \\
\text { estadual ou } \\
\text { federal (há } \\
\text { prazos de } \\
\text { defesa para } \\
\text { município). }\end{array}$ \\
\hline
\end{tabular}

Fonte: Elaboração própria. 
O Quadro 3 resume a aplicação dos quatro eixos na análise das transferências selecionadas para a área da assistência social. Quanto à especificação do uso dos recursos pelos governos receptores nos níveis subnacionais, há variações: se, no caso do IGD, a especificação é relativamente ampla, no piso social especializado / Programa de Erradicação do Trabalho Infantil - PETI/JOR, ele é de uso restrito ao programa (manutenção e pagamento de bolsa aos jovens incluídos no programa). Entre ambos, o caráter mais ou menos restrito depende do objeto do programa, ou seja, se voltado para a família (mais amplo), se para o idoso e a criança, ou ao jovem (mais específico). De qualquer forma, há sempre delimitação para o uso dos recursos considerando o programa financiado.

Quanto ao monitoramento e controle do uso de recursos, no caso do IGD, essas funções cabem diretamente ao Ministério do Desenvolvimento Social (MDS) com base nas prestações de contas municipais, padrão que se estende aos casos dos programas vinculados ao Sistema Único de Assistência Social (Suas), em que o MDS se utiliza de sistemas de informação alimentados pelos municípios, enquanto os gestores estaduais realizam visitas in loco para verificação.

A inclusão de outros atores no controle do uso dos recursos, no caso do Suas, também passa, como no caso do SUS, por mobilizar os mecanismos de controle societal nos níveis subnacionais - municípios e estados - no acompanhamento das prestações de contas dos respectivos gestores, com disponibilização das mesmas para os órgãos de controle externo, como os tribunais de contas e o Ministério Público.

Por fim, as principais sanções previstas na execução dos recursos, assim como ocorre no caso do setor saúde, se referem ao bloqueio ou suspensão da transferência de recursos em casos previamente tipificados. No caso do IGD, essas sanções poderiam se dar virtude de manipulação de informações relativas aos seus parâmetros ou envio de informações inverídicas, já no caso do PETI/JOR poderiam ocorrer em virtude de não atualização dos dados do programa informatizado específico. 


\section{Quadro 3 - Análise dos mecanismos de transferências de recursos para governos subnacionais no setor assistência social}

\begin{tabular}{|c|c|c|c|c|c|}
\hline \multirow[b]{2}{*}{$\begin{array}{l}\text { Mecanismo de } \\
\text { transferência }\end{array}$} & \multirow[b]{2}{*}{ Destinação } & \multicolumn{4}{|c|}{ Eixos de análise } \\
\hline & & $\begin{array}{l}\text { Especificação } \\
\text { destinação dos } \\
\text { recursos }\end{array}$ & $\begin{array}{l}\text { Monitoramento e } \\
\text { controle direto }\end{array}$ & $\begin{array}{l}\text { Monitoramento e } \\
\text { controle outros }\end{array}$ & $\begin{array}{l}\text { Sanção desvio de } \\
\text { finalidade }\end{array}$ \\
\hline IGD & $\begin{array}{c}\text { Retribuir } \\
\text { bom } \\
\text { desempenho } \\
\text { do governo } \\
\text { local na } \\
\text { manutenção } \\
\text { atualizada } \\
\text { de dados do } \\
\text { cadastro do } \\
\text { PBF. }\end{array}$ & \begin{tabular}{|} 
Aquisições diversas \\
para realizar \\
ações diversas \\
que fortaleçam \\
atividades correlatas \\
ao PBF (qualidade \\
do cadastro; \\
acompanhamento de \\
condicionalidades; \\
gestão dos benefícios; \\
oportunidades para \\
famílias beneficiárias), \\
portanto há razoável \\
flexibilidade na \\
destinação.
\end{tabular} & \begin{tabular}{|c|} 
MDS / Secretaria \\
Nacional de Renda \\
de Cidadania \\
(Senarc) averigua a \\
prestação de contas \\
relativa aos recursos \\
transferidos (na \\
prestação de \\
contas anual dos \\
respectivos fundos \\
municipais de \\
assistência social). \\
\end{tabular} & \begin{tabular}{|} 
Prestação de contas \\
às "instâncias de \\
controle social" \\
(conselhos \\
municipais de \\
assistência social) \\
disponível para \\
"qualquer órgão de \\
controle interno e \\
externo".
\end{tabular} & \begin{tabular}{|} 
Interrupção \\
provisória pelo \\
MDS pode se dar \\
por: manipulação \\
de informações \\
relativas aos \\
parâmetros do \\
IGD; envio de \\
informações \\
inverídicas ao MDS; \\
perda da gestão \\
municipal da \\
assistência social; e \\
denúncia.
\end{tabular} \\
\hline PBF - família & $\begin{array}{l}\text { Financiar } \\
\text { serviços e } \\
\text { ações do } \\
\text { piso básico } \\
\text { / família no } \\
\text { Suas. }\end{array}$ & \begin{tabular}{|} 
Aquisições diversas \\
para as diversas \\
ações do Programa \\
de Atenção \\
Integral à Família \\
- padronização \\
nacional (entrevistas, \\
visitas domiciliares, \\
palestras, \\
oficinas, grupos \\
de convivência, \\
atividades lúdicas, \\
entre outras). \\
Embora uso seja \\
amplo, é vedada \\
utilização do piso \\
básico fixo para \\
financiamento de \\
benefícios eventuais.
\end{tabular} & $\begin{array}{c}\text { Internamente via } \\
\text { MDS / Secretaria } \\
\text { Nacional de } \\
\text { Assistência Social } \\
\text { (SNAS ), via sistema } \\
\text { de informação, e } \\
\text { estados (visitas in } \\
\text { loco). }\end{array}$ & \begin{tabular}{|c|} 
Relatórios de \\
gestão municipais \\
e estaduais, \\
aprovados nos \\
respectivos \\
conselhos, \\
disponibilizados \\
para o Poder \\
Legislativo e \\
Ministério Público.
\end{tabular} & $\begin{array}{l}\text { Secretaria Nacional } \\
\text { de Assistência } \\
\text { Social / MDS } \\
\text { (dependendo do } \\
\text { caso, bloqueio, } \\
\text { suspensão } \\
\text { ou devolução } \\
\text { dos recursos } \\
\text { repassados). }\end{array}$ \\
\hline $\begin{array}{c}\text { PBT - PSB - } \\
\text { idoso/infância }\end{array}$ & $\begin{array}{l}\text { Financiar } \\
\text { serviços e } \\
\text { ações do } \\
\text { piso básico } \\
\text { / idosos e } \\
\text { infância no } \\
\text { Suas. }\end{array}$ & $\begin{array}{c}\text { Aquisições diversas } \\
\text { para ações de } \\
\text { proteção social básica } \\
\text { relativas aos serviços } \\
\text { - padronização } \\
\text { nacional: I - Jornada } \\
\text { Integral - JOI e } \\
\text { Jornada Parcial - JOPA } \\
\text { para crianças de 0 } \\
\text { a } 6 \text { anos e Ações } \\
\text { Socioeducativas de } \\
\text { Apoio à Família de } \\
\text { crianças de } 0 \text { a } 6 \text { anos } \\
\text { - ASEF; } \\
\text { II - Centros e Grupos } \\
\text { de Convivência para } \\
\text { Idosos. Destinação } \\
\text { é exclusiva para } \\
\text { ações relativas ao } \\
\text { programa. }\end{array}$ & $\begin{array}{c}\text { Internamente } \\
\text { via MDS / SNAS } \\
\text { (sistema de } \\
\text { informação) e } \\
\text { estados (visitas in } \\
\text { loco). }\end{array}$ & \begin{tabular}{|} 
Relatórios de \\
gestão municipais \\
e estaduais, \\
aprovados nos \\
respectivos \\
conselhos, \\
disponibilizados \\
para o Poder \\
Legislativo e \\
Ministério Público.
\end{tabular} & $\begin{array}{l}\text { Secretaria Nacional } \\
\text { de Assistência } \\
\text { Social / MDS } \\
\text { (dependendo do } \\
\text { caso, bloqueio, } \\
\text { suspensão } \\
\text { ou devolução } \\
\text { dos recursos } \\
\text { repassados). }\end{array}$ \\
\hline
\end{tabular}




\begin{tabular}{|c|c|c|c|c|c|}
\hline \multirow[b]{2}{*}{$\begin{array}{c}\text { Mecanismo de } \\
\text { transferência }\end{array}$} & \multirow[b]{2}{*}{ Destinação } & \multicolumn{4}{|c|}{ Eixos de análise } \\
\hline & & $\begin{array}{l}\text { Especificação } \\
\text { destinação dos } \\
\text { recursos }\end{array}$ & $\begin{array}{l}\text { Monitoramento e } \\
\text { controle direto }\end{array}$ & $\begin{array}{l}\text { Monitoramento e } \\
\text { controle outros }\end{array}$ & $\begin{array}{l}\text { Sanção desvio de } \\
\text { finalidade }\end{array}$ \\
\hline PSE - PETI/ JOR & $\begin{array}{c}\text { Financiar } \\
\text { ações para } \\
\text { erradicação } \\
\text { do trabalho } \\
\text { infantil no } \\
\text { âmbito do } \\
\text { Suas. }\end{array}$ & \begin{tabular}{|} 
Pagamento de \\
bolsas, monitorias \\
e usos diversos \\
para manutenção \\
de serviço de \\
convivência e \\
fortalecimento \\
de vínculos para \\
crianças inseridas no \\
programa. \\
Destinação \\
exclusiva para a \\
rubrica de custeio, \\
especificamente nas \\
ações relativas ao \\
programa.
\end{tabular} & $\begin{array}{c}\text { Internamente via } \\
\text { monitoramento dos } \\
\text { estados e União } \\
\text { (MDS / SNAS), sendo } \\
\text { que os primeiros } \\
\text { assumem grande } \\
\text { parte dos custos de } \\
\text { implementação do } \\
\text { programa (validação, } \\
\text { supervisão, } \\
\text { acompanhamento, } \\
\text { entre outros). } \\
\end{array}$ & \begin{tabular}{|} 
Relatórios de \\
gestão municipais \\
e estaduais, \\
aprovados nos \\
respectivos \\
conselhos, \\
disponibilizados \\
para o Poder \\
Legislativo e \\
Ministério Público.
\end{tabular} & $\begin{array}{c}\text { Executivo federal } \\
\text { pode interromper } \\
\text { transferência com } \\
\text { base no SISPETI, } \\
\text { em caso de não } \\
\text { atualização de } \\
\text { dados do programa, } \\
\text { ou suspender } \\
\text { a pedido do } \\
\text { município que } \\
\text { tenham erradicado } \\
\text { o trabalho infantil. }\end{array}$ \\
\hline $\begin{array}{l}\text { PSB- PBV } 1 \text { - } \\
\text { Projovem }\end{array}$ & $\begin{array}{l}\text { Financiar } \\
\text { serviços e } \\
\text { ações do } \\
\text { piso básico } \\
\text { / jovens no } \\
\text { Suas. }\end{array}$ & \begin{tabular}{|} 
Aquisições diversas \\
relativas ao objeto do \\
programa incluindo \\
contratação, \\
remuneração \\
e formação de \\
profissionais. \\
Destinação é exclusiva \\
para ações relativas \\
ao programa.
\end{tabular} & $\begin{array}{c}\text { Internamente } \\
\text { via MDS / SNAS } \\
\text { (sistema de } \\
\text { informação) e } \\
\text { estados (visitas in } \\
\text { loco). }\end{array}$ & \begin{tabular}{|c|} 
Relatórios de \\
gestão municipais \\
e estaduais, \\
aprovados nos \\
respectivos \\
conselhos, \\
disponibilizados \\
para o Poder \\
Legislativo e \\
Ministério Público.
\end{tabular} & \begin{tabular}{|} 
Secretaria Nacional \\
de Assistência \\
Social / MDS \\
(dependendo do \\
caso, bloqueio, \\
suspensão \\
ou devolução \\
dos recursos \\
repassados)
\end{tabular} \\
\hline
\end{tabular}

Fonte: Elaboração própria.

O Quadro 4 resume a aplicação dos quatro eixos na análise das transferências selecionadas para a área da educação. Quanto à especificação do uso dos recursos pelos governos receptores nos níveis subnacionais, os mecanismos apresentam padrões bastante distintos. De um lado o Salário Educação, o Fundeb e o PDDE apresentam objeto mais amplo, e o uso de recursos é relativamente flexível. Nos dois primeiros, desde que direcionado para a educação básica, havendo alguns condicionantes no caso do Fundeb, principalmente quanto à proporção de recursos a ser dedicada ao gasto com pessoal. No caso dos demais mecanismos, cujos programas correspondentes atendem a objetos mais específicos - merenda e transporte escolar -, não há flexibilidade, e a destinação é restrita.

Quanto ao monitoramento e controle do uso de recursos, pode-se dizer que o papel central é desempenhado pelo Fundo Nacional de Desenvolvimento da Educação (FNDE) em todos eles.

A inclusão de outros atores no controle do uso dos recursos inclui mecanismos de controle societal que, diferentemente do caso da saúde e da assistência social, 
se constituem de forma fragmentada em torno de cada um deles em se tratando do Fundeb, PNAE e PNATE. De outro lado, o envolvimento dos tribunais de contas dos estados e da União, além do Ministério Público, é explicitado nas respectivas leis que criam os distintos mecanismos de transferência.

Por fim, quanto à possibilidade de aplicação de sanções relativas à execução dos recursos, há casos bastante distintos. Para o Salário Educação e Fundeb, as sanções dependem de análise dos órgãos de controle externo, não estando a União previamente autorizada a, unilateralmente, realizar bloqueios ou suspensão de transferências que, a rigor, são obrigatórias. Nos casos do PNAE, PDDE e PNATE, o FNDE está autorizado a suspender transferências e, se for o caso, estornar valores transferidos em casos como omissão ou não aprovação de prestação de contas pelos governos subnacionais.

\section{Quadro 4 - Análise dos mecanismos de transferências de recursos para governos subnacionais no setor de educação}

\begin{tabular}{|c|c|c|c|c|c|}
\hline \multirow{2}{*}{$\begin{array}{l}\text { Mecanismo de } \\
\text { transferência }\end{array}$} & \multirow{2}{*}{ Destinação } & \multicolumn{4}{|c|}{ Eixos de análise } \\
\hline & & $\begin{array}{l}\text { Especificação destinação } \\
\text { dos recursos }\end{array}$ & $\begin{array}{l}\text { Monitoramento e } \\
\text { controle direto }\end{array}$ & $\begin{array}{c}\text { Monitoramento e } \\
\text { controle outros }\end{array}$ & $\begin{array}{l}\text { Sanção desvio de } \\
\text { finalidade }\end{array}$ \\
\hline $\begin{array}{l}\text { Salário } \\
\text { educação }\end{array}$ & \begin{tabular}{|} 
Financiar \\
programas, \\
projetos \\
e ações \\
voltados para \\
educação \\
básica.
\end{tabular} & $\begin{array}{l}\text { Aquisições diversas para } \\
\text { o financiamento de } \\
\text { programas, projetos e } \\
\text { ações da educação básica, } \\
\text { podendo ser aplicados na } \\
\text { educação especial, desde } \\
\text { que vinculada ao ensino } \\
\text { fundamental público. } \\
\text { Remanejamentos possíveis, } \\
\text { desde que para a educação } \\
\text { básica. }\end{array}$ & $\begin{array}{l}\text { Internamente } \\
\text { ao Executivo, } \\
\text { fiscalização por } \\
\text { intermédio do } \\
\text { FNDE, na forma do } \\
\text { regulamento e das } \\
\text { instruções baixadas } \\
\text { por essa autarquia. }\end{array}$ & $\begin{array}{c}\text { Tribunais de contas } \\
\text { dos estados e da } \\
\text { União. }\end{array}$ & $\begin{array}{c}\text { O Poder Executivo } \\
\text { não pode realizar } \\
\text { suspensão } \\
\text { unilateral das } \\
\text { transferências, que } \\
\text { são obrigatórias. }\end{array}$ \\
\hline $\begin{array}{l}\text { Fundeb / } \\
\text { Fundef }\end{array}$ & $\begin{array}{l}\text { Financiar } \\
\text { serviços de } \\
\text { educação } \\
\text { básica. }\end{array}$ & \begin{tabular}{|} 
Aquisições diversas no \\
exercício financeiro em \\
que forem creditados, \\
em ações consideradas \\
como de manutenção \\
e desenvolvimento do \\
ensino para a educação \\
básica pública; proporção \\
não inferior $60 \%$ \\
para pagamento dos \\
profissionais do magistério \\
em efetivo exercício; até $5 \%$ \\
poderão no 10 trimestre do \\
exercício imediatamente \\
subsequente. Vedada \\
utilização fora da educação \\
básica ou como garantia ou \\
contrapartida de operações \\
de crédito, internas ou \\
externas.
\end{tabular} & \begin{tabular}{|} 
União monitora \\
aplicação dos \\
recursos dos \\
fundos, por meio \\
de sistema de \\
informações \\
orçamentárias e \\
financeiras. \\
\end{tabular} & $\begin{array}{c}\text { Fiscalização e } \\
\text { controle exercidos } \\
\text { pelos conselhos } \\
\text { dos fundos e pelos } \\
\text { órgãos de controle } \\
\text { interno de cada } \\
\text { ente federado. } \\
\text { Controle externo: } \\
\text { tribunais de contas } \\
\text { dos estados e da } \\
\text { União. }\end{array}$ & $\begin{array}{l}\text { Não há suspensão } \\
\text { unilateral das } \\
\text { transferências, que } \\
\text { são obrigatórias, } \\
\text { uma vez presentes } \\
\text { as condições para } \\
\text { sua realização } \\
\text { (necessidade } \\
\text { para que sejam } \\
\text { atingidos os } \\
\text { valores per capita } \\
\text { previamente } \\
\text { estabelecidos). }\end{array}$ \\
\hline
\end{tabular}




\begin{tabular}{|c|c|c|c|c|c|}
\hline \multirow[b]{2}{*}{$\begin{array}{l}\text { Mecanismo de } \\
\text { transferência }\end{array}$} & \multirow[b]{2}{*}{ Destinação } & \multicolumn{4}{|c|}{ Eixos de análise } \\
\hline & & $\begin{array}{c}\text { Especificação destinação } \\
\text { dos recursos }\end{array}$ & $\begin{array}{l}\text { Monitoramento e } \\
\text { controle direto }\end{array}$ & $\begin{array}{l}\text { Monitoramento e } \\
\text { controle outros }\end{array}$ & $\begin{array}{l}\text { Sanção desvio de } \\
\text { finalidade }\end{array}$ \\
\hline $\begin{array}{c}\text { PNAE } \\
\text { (alimentação) }\end{array}$ & \begin{tabular}{|c|} 
\\
Financiar for- \\
necimento \\
de alimenta- \\
ção escolar. \\
\\
\end{tabular} & $\begin{array}{c}\text { Restrita à aquisição dos } \\
\text { gêneros alimentícios, } \\
\text { obedecendo planejamento } \\
\text { nutricional realizado pelo } \\
\text { ente federativo em que } \\
\text { se localizam as escolas; } \\
\text { no mínimo 30\% para } \\
\text { aquisições da agricultura } \\
\text { familiar e empreendedor } \\
\text { familiar rural, dispensando- } \\
\text { se licitação quando preços } \\
\text { compatíveis com mercado } \\
\text { local. Não há flexibilidade } \\
\text { de remanejamento: saldos } \\
\text { remanescentes em } 31 / 12 \\
\text { deverão ser reprogramados } \\
\text { para o exercício } \\
\text { subsequente, com estrita } \\
\text { observância ao objeto de } \\
\text { sua transferência. }\end{array}$ & \begin{tabular}{|l|} 
Auditagem do FNDE \\
a cada exercício \\
financeiro, por \\
amostragem, \\
mediante inspeções \\
e análise dos \\
processos com \\
prestações de \\
contas. \\
\end{tabular} & \begin{tabular}{|} 
FNDE envia \\
dados financeiros \\
para câmaras \\
legislativas, \\
Ministério Público \\
e conselhos de \\
alimentação \\
escolar. Após \\
aprovação de \\
contas do FNDE no \\
TCU, documentos \\
à disposição do \\
Ministério Público e \\
órgãos de controle \\
externo. \\
\end{tabular} & $\begin{array}{l}\text { União pode } \\
\text { suspender } \\
\text { se estados e } \\
\text { municípios não } \\
\text { cumprirem } \\
\text { obrigações } \\
\text { no programa } \\
\text { (constituição do } \\
\text { CAE, apresentar } \\
\text { prestação de } \\
\text { contas do PNAE, } \\
\text { na forma e prazos } \\
\text { estabelecidos } \\
\text { pelo FNDE). FNDE } \\
\text { pode estornar } \\
\text { valores em casos } \\
\text { como depósitos } \\
\text { indevidos, } \\
\text { irregularidades na } \\
\text { execução e outros. }\end{array}$ \\
\hline $\begin{array}{l}\text { PDDE (dinheiro } \\
\text { direto) }\end{array}$ & \begin{tabular}{|c|} 
Financiar \\
pequenas \\
despesas e \\
investimen- \\
tos em esco- \\
las no ensino \\
básico. \\
\end{tabular} & $\begin{array}{c}\text { Aquisições para custeio e } \\
\text { pequenos investimentos em } \\
\text { funcionamento e melhoria } \\
\text { da infraestrutura física } \\
\text { e pedagógica de escolas } \\
\text { (material permanente; } \\
\text { manutenção, conservação } \\
\text { e pequenos reparos; } \\
\text { aquisição de material de } \\
\text { consumo; avaliação de } \\
\text { aprendizagem; atividades } \\
\text { educacionais; e outros). } \\
\text { Lei veda explicitamente } \\
\text { gastos com pessoal, outros } \\
\text { itens do ensino básico já } \\
\text { financiados pelo FNDE, } \\
\text { entre outros. }\end{array}$ & $\begin{array}{c}\text { FNDE faz auditorias, } \\
\text { inspeções e análise } \\
\text { dos processos } \\
\text { com prestações de } \\
\text { contas. }\end{array}$ & $\begin{array}{c}\text { Após aprovação de } \\
\text { contas do FNDE no } \\
\text { TCU, documentos } \\
\text { à disposição do } \\
\text { Ministério Público e } \\
\text { órgãos de controle } \\
\text { externo. }\end{array}$ & $\begin{array}{c}\text { FNDE pode } \\
\text { suspender em } \\
\text { casos como } \\
\text { omissão na } \\
\text { prestação de } \\
\text { contas ou rejeição } \\
\text { da prestação } \\
\text { de contas. Pode } \\
\text { estornar valores } \\
\text { ou bloquear } \\
\text { transferência } \\
\text { em casos como } \\
\text { depósitos } \\
\text { indevidos, } \\
\text { paralisação das } \\
\text { atividades ou } \\
\text { extinção da escola } \\
\text { vinculada e outros. }\end{array}$ \\
\hline $\begin{array}{c}\text { PNATE } \\
\text { (transporte) }\end{array}$ & $\begin{array}{l}\text { Financiar } \\
\text { provisão de } \\
\text { transporte } \\
\text { escolar. }\end{array}$ & $\begin{array}{l}\text { Aquisições diversas } \\
\text { relativas ao transporte } \\
\text { escolar incluindo: reforma, } \\
\text { seguros, licenciamento, } \\
\text { impostos e taxas, pneus, } \\
\text { câmaras e serviços de } \\
\text { mecânica, combustível } \\
\text { e lubrificantes, ou, no } \\
\text { que couber, embarcação, } \\
\text { serviços contratados } \\
\text { junto a terceiros e outros } \\
\text { aprovados pelo FNDE. } \\
\text { Não há possibilidade de } \\
\text { realocação para outras } \\
\text { ações educacionais. }\end{array}$ & \begin{tabular}{|c|} 
Fiscalização da \\
aplicação dos \\
recursos financeiros \\
pelo MEC / FNDE \\
(auditorias, \\
fiscalizações, \\
inspeções e análise \\
das prestações de \\
contas). \\
\end{tabular} & $\begin{array}{c}\text { Conselhos de } \\
\text { fundos instituídos } \\
\text { nos estados e } \\
\text { municípios, órgãos } \\
\text { de controle interno } \\
\text { do Executivo } \\
\text { Federal. Controle } \\
\text { externo: tribunais } \\
\text { de contas dos } \\
\text { estados e da União. }\end{array}$ & $\begin{array}{l}\text { FNDE pode } \\
\text { suspender em } \\
\text { casos como } \\
\text { omissão na } \\
\text { prestação de } \\
\text { contas ou rejeição } \\
\text { da prestação de } \\
\text { contas. }\end{array}$ \\
\hline
\end{tabular}

Fonte: Elaboração própria. 
Diante da análise dos mecanismos de transferência utilizados nos três setores governamentais, algumas constatações de caráter geral são possíveis.

Em primeiro lugar, identifica-se, em todos os mecanismos estudados - os que mobilizam o maior aporte de recurso nas respectivas áreas governamentais, ocupando também posição central na organização dos serviços ofertados à população -, a clara especificação do leque de ações a serem implementadas pelos governos subnacionais e do tipo de despesa a ser executada para tanto. A despeito de maior flexibilidade para alocação em alguns casos, é clara a vinculação dos mesmos aos propósitos proclamados nos respectivos programas.

Em segundo lugar, os diferentes setores governamentais estudados dispõem de estruturas para monitoramento e controle do comportamento dos governos subnacionais - Sistema Nacional de Auditoria do SUS; Secretaria Nacional de Assistência Social do MDS e o FNDE, no caso da educação -, embora elas sejam incrementadas pelo compartilhamento dessas funções com outros agentes societais - conselhos de políticas públicas na saúde e assistência social ou de controle em programas específicos, no caso da educação - e de controle externo, como os tribunais de contas e o Ministério Público.

Em terceiro, via de regra, as bases legais e normativas dos mecanismos de transferência preveem procedimentos para sanção unilateral, notadamente suspensão das transferências intergovernamentais, ainda que, também via de regra, incluindo o direito de defesa ou a possibilidade de readequação do comportamento dos governos subnacionais, para que possam retomar a recepção dos recursos.

Em linhas gerais, a partir daí, pode-se concluir que os referidos mecanismos de transferências contêm procedimentos que incorporam alguns dos atributos institucionais importantes para que, numa relação de agência, o polo outorgante possa estruturar incentivos adequados para a atuação dos outorgados. Há especificação, pelo principal, das ações a serem desempenhadas pelos agents, no sentido de instruí-los sobre como se comportar, e o primeiro dispõe de mecanismos para o monitoramento de tal comportamento, a fim de adquirir informações que Ihe permitam avaliar estarem os últimos, ou não, agindo no seu melhor interesse. O Executivo federal, na sua posição de principal, se beneficia da atuação de outros atores institucionais no monitoramento do comportamento dos agents, atores institucionais que, por esse motivo, poderiam ser qualificados como múltiplos principals. Além disso, há previsão de procedimentos de sanção dos comportamentos inadequados e correção dos mesmos.

Por fim, dada a exigência constitucional de garantias sociais plenas nas políticas públicas analisadas, em um contexto de descentralização das responsabilidades de implementação para os governos subnacionais sob elevado nível de fragmentação 
territorial com o elevado número de municípios, pode-se supor que os mecanismos de transferências de recursos se colocam como uma opção realista para a coordenação federativa. Nos formatos vigentes, aqui analisados, eles foram desenhados de forma a reduzir custos de agência, padronizando e delimitando as ações a serem executadas por governos subnacionais, condicionando o repasse de recursos à realização dessas ações e dispondo de uma multiplicidade de "controladores" que permite minimizar os problemas de déficit informacional, ao mesmo tempo em que reduz os custos de agência para o próprio Executivo federal.

Porém, detendo regras e condições específicas para execução dos recursos transferidos, os programas que vão se somando aos já existentes, em cada um dos setores analisados, podem estar conduzindo a uma fragmentação vertical (programática) das ações governamentais locais em políticas sociais. Se, em muitos casos, eles podem ser complementar, internamente a cada setor, dificilmente isso ocorre, de modo que a indução vertical pela via de diversos programas paralelos pode estar inibindo ou dificultando o desenvolvimento de iniciativas intersetoriais na esfera local, aspecto que poderá ser avaliado em estudos futuros.

\section{Comentários finais}

A difusão dos mecanismos de transferência condicionada de recursos para finalidades específicas, nas três áreas governamentais aqui estudadas, tem permitido ao Executivo federal lidar com o problema da fragmentação territorial produzida pelo federalismo trino brasileiro, em sentido horizontal, diante da necessidade de implementação de políticas públicas de caráter nacional.

Mas não se pode concluir, daí, que as relações entre Governo Federal e governos subnacionais se resuma às relações de agência, tipicamente características de um federalismo centralizado. Como já dito no início deste trabalho, as transferências de recursos para governos subnacionais têm sido uma das principais molas propulsoras na implementação de políticas ou programas, porém juntamente com outros mecanismos de coordenação federativa utilizados no pós 88. Entre estes, como já dito, estão as arenas de compartilhamento de decisões sobre a operacionalização da implementação dessas políticas, que agregam elementos mais próprios do federalismo cooperativo, ainda que em outro trabalho tenhamos tratado da mitigação dos traços típicos deste último diante dos recursos assimétricos de que dispõe o Executivo federal nesses fóruns (MACHADO; PALOTTI, 2015).

Não obstante esse último ponto, seria um erro resumir o padrão de relações intergovernamentais vigente às relações de agência entre Governo Federal e governos subnacionais, o que não nos impede de registrar que parte significativa do volume de recursos mobilizado e dos processos de formulação e implementação das políticas públicas sociais se deem sob parâmetros que definem tais relações. 
Aceita essa constatação, algumas hipóteses para estudos futuros são promissoras, enquanto referindo-se à produção de transbordamentos sob tais relações.

Em uma primeira direção, outros mecanismos ou dispositivos típicos do federalismo cooperativo poderiam ser contaminados pelas relações de agência estruturadas por meio das transferências condicionadas para programas ou ações desenhadas pelo Executivo Federal. O poder de agenda e de persuasão, além do acesso diferenciado a informações, por parte dos representantes deste último nas comissões intergestores tripartite da saúde e a da assistência social, por exemplo, ganhariam importante reforço sob essas transferências. A presença de uma burocracia formuladora e a disponibilidade de receitas federais, combinada a um contexto de constrangimento fiscal dos governos subnacionais, tornariam as iniciativas do Executivo Federal ainda mais atraentes, mesmo em arenas paritárias em que, em tese, os governos subnacionais teriam poder de veto. Além disso, mesmo as parcerias pela via dos consórcios públicos poderiam já apresentar algum nível importante de dependência, na sua formação ou manutenção, de iniciativas e incentivos financeiros dos estados ou da União (MACHADO; PALOTTI, 2015).

Em uma segunda direção, os hipotéticos transbordamentos a que aqui nos referimos podem ser tomados também em conexão com o caráter de superação da fragmentação horizontal, sob as transferências financeiras verticais para finalidades específicas a partir do Executivo federal. Tal superação poderia ser parte, paradoxalmente, da produção e manutenção da fragmentação dos programas sociais entre as diferentes áreas governamentais, no espaço de atuação dos governos subnacionais. Tendo de se submeter a regras bastante específicas para execução de despesas, inscritas sob uma infinidade de mecanismos de transferências financeiras federais, sob as quais estão sujeitos a controles e riscos de sanções, governos estaduais e municipais teriam dificuldades ainda maiores de integração programática ou de coordenar, internamente, ações intersetoriais.

Por fim, se confirmado esse último efeito de transbordamento, ele nos apontaria para um trade-off: se superam a fragmentação horizontal (municípios) numa dimensão intergovernamental, acirram a fragmentação vertical (programática) numa dimensão intragovernamental; se forem suficientemente flexíveis para permitir maior integração vertical programática em nível local, poderiam não ser potentes para superar a fragmentação horizontal entre decisões tomadas por diferentes jurisdições locais. Assim sendo, é possível que, além da autonomia local, a fragmentação programática também possa ser contabilizada no preço pago pelo federalismo brasileiro para lograr os ganhos de coordenação necessários para assegurar o caráter igualitário e redistributivo das políticas sociais. 


\section{Referências bibliográficas}

ABRUCIO, Fernando Luís. A coordenação federativa no Brasil: a experiência do período FHC e os desafios do governo Lula. Revista de Sociologia e Política, n. 24, p. 31-67, 2005.

ALMEIDA, Maria Hermínia T. Federalismo e proteção social: a experiência brasileira em perspectiva comparada. Trabalho apresentado no Seminário Pacto Federativo e Guerra Fiscal no Brasil. São Paulo: FGV, 2000.

Recentralizando a Federação? Revista de Sociologia e Política, n. 24, p. 29-40, 2005.

O Estado no Brasil contemporâneo: um passeio pela história. In: Melo, C. R.; SÁEz, M. A. (Orgs.). A democracia brasileira: balanço e perspectivas para o século 21. Belo Horizonte: Editora UFMG, 2007.

ARRETCHE, Marta. Financiamento federal e gestão local de políticas sociais: o difícil equilíbrio entre regulação, responsabilidade e autonomia. Revista Ciência e Saúde Coletiva, Rio de Janeiro, v. 8, n. 2, p. 331-345, 2003.

Federalismo e políticas sociais no Brasil: problemas de coordenação e autonomia. São Paulo em Perspectiva, v. 18, n. 2, p. 17-26, 2004.

Continuidades e descontinuidades da Federação brasileira: de como 1988 facilitou 1995. Dados, v. 52, n. 2, p. 377-423, 2009.

Democracia, federalismo e centralização no Brasil. Rio de Janeiro: FGV / Fiocruz, 2012.

FRANZeSE, Cibele. Federalismo cooperativo no Brasil: da Constituição de 1988 aos sistemas de políticas públicas. São Paulo: Escola de Administração de Empresas de São Paulo, 2010. Tese (Doutorado) - Escola de Administração de Empresas de São Paulo, São Paulo.

LEVAGGI, Rosella. Decentralized budgeting procedures for public expenditure. Public Finance Review, n. 30, p. 273-295, 2002.

LÖFLER, E. A gestão da responsabilização nas parcerias intergovernamentais. Revista do Serviço Público, v. 51, n. 2, p. 5-34, 2000.

MACHADO, José Angelo. Relatório de pesquisa: relações intergovernamentais $e$ coordenação de políticas sociais: eficácia e contenção do poder no desenho dos incentivos financeiros federais (Apoio Financeiro CNPq / FAPEMIG). Belo Horizonte: UFMG, 2011.

MACHADO, José Angelo; PALOTTI, Pedro Lucas M. Entre cooperação e centralização: federalismo e políticas sociais no Brasil pós 88. Revista Brasileira de Ciências Sociais, v. 30, n. 88, p. 61-82, 2015.

MILLER, Gary J. The political evolution of principal-agents model. Annual Review of Political Science, v. 8, p. 203-225, 2005.

OATES, Wallace. Toward a second-generation Theory of Fiscal Federalism. International Tax and Public Finance, v. 12, p. 349-373, 2005. 
PALOtTI, P. Coordenação federativa e a "armadilha da decisão conjunta": as comissões de articulação intergovernamental das políticas sociais no Brasil. Dissertação (Mestrado), UFMG, Belo Horizonte, 2012.

PRZEWORSKI, Adam. The State and the citizen. Paper apresentado no Seminário Internacional Sociedade e a Reforma do Estado. São Paulo: 1998.

Ross, Stephen A. The economic theory of agency: the principals problem. American Economic Association, v. 63, n. 2, p. 134-139, 1973.

SouzA, Celina. Federalismo, desenho constitucional e instituições federativas no Brasil pós-1988. Revista de Sociologia e Política, n. 24, p. 105-121, 2005.

SouzA, C. Instituições e Mudanças: reformas da Constituição de 1988, federalismo e políticas públicas In: Hochman, G.; FARIA, C. A. P. (Orgs.). Federalismo e Políticas Públicas no Brasil. Rio de Janeiro: Editora FIOCRUZ, 2013.

José Angelo Machado

Possui doutorado em Ciências Humanas pela Universidade Federal de Minas Gerais (UFMG). Atualmente é Professor Associado do Departamento de Ciência Política da UFMG. Contato: joseangelo@fafich.ufmg.br 
RSP 